\title{
Cytotoxic activity and apoptotic induction of some edible Thai local plant extracts against colon and liver cancer cell lines
}

\author{
Pornhathai Putthawan', Supattra Poeaim ${ }^{2}$, Varipat Areekul ${ }^{1 *}$ \\ ${ }^{1}$ Faculty of Agro-Industry, ${ }^{2}$ Department of Biology, Faculty of Science, King Mongkut's Institute of Technology. Ladkrabang, \\ Bangkok 10520, Thailand
}

*For correspondence: Email: Varipat.ar@kmitl.ac.th; Tel: +66-23298526

Sent for review: 4 August 2017

Revised accepted: 17 November 2017

\begin{abstract}
Purpose: To evaluate eight edible Thai local plant extracts (Camellia sinensis, Careya sphaerica, Cratoxylum formosum, Eleutherococcus trifoliatus, Ficus auriculata, Persicaria odorata, Schima wallichii, and Vaccinium sprengelii) against colon and liver cancer cell lines.

Methods: The $80 \%$ ethanol plant extracts were screened for cytotoxic activity against human colon adenocarcinoma (HT-29) and human hepatocellular carcinoma (HepG2) cells by MTT assay. The $50 \%$ cytotoxic activity concentration $\left(\mathrm{CC}_{50}\right)$ was then determined. Apoptotic cell death was observed by inverted microscopy and DNA fragmentation using agarose gel electrophoresis.

Results: P. odorata and S. wallichii extracts showed strong cytotoxic activity, with the latter exhibiting more potent cytotoxic activity than the former. The $C C_{50}$ value of $S$. wallichii extract was 453 and 367 $\mu \mathrm{g} / \mathrm{mL}$ against HT-29 and HepG2 cells, respectively. In contrast, $P$. odorata extract showed $C_{50}$ value of $775 \mu \mathrm{g} / \mathrm{mL}$ against HT-29 and $1665 \mu \mathrm{g} / \mathrm{mL}$ against HepG2 cells. Microscopic observations indicate that the degree of morphological changes was concentration-dependent. The cell lines treated with both plant extracts displayed apoptosis.

Conclusion: The two plant extracts have high potentials for medicinal use in colon and liver cancer management. However, further studies are needed to isolate the active compounds responsible for the cytotoxic activities.
\end{abstract}

Keywords: Edible Thai local plants, Cytotoxic activity, Apoptotic induction, Colon cancer, Liver cancer

\begin{abstract}
This is an Open Access article that uses a funding model which does not charge readers or their institutions for access and distributed under the terms of the Creative Commons Attribution License (http://creativecommons.org/licenses/by/4.0) and the Budapest Open Access Initiative (http://www.budapestopenaccessinitiative.org/read), which permit unrestricted use, distribution, and reproduction in any medium, provided the original work is properly credited.
\end{abstract}

Tropical Journal of Pharmaceutical Research is indexed by Science Citation Index (SciSearch), Scopus, International Pharmaceutical Abstract, Chemical Abstracts, Embase, Index Copernicus, EBSCO, African Index Medicus, JournalSeek, Journal Citation Reports/Science Edition, Directory of Open Access Journals (DOAJ), African Journal Online, Bioline International, Open-J-Gate and Pharmacy Abstracts

\section{INTRODUCTION}

The numbers of cancer patients have increased every year and cancer is the second cause of death worldwide. This non-communicable disease is characterized by uncontrollable proliferation of abnormal cells. It is accompanied by uncontrolled development of cells, which have a tendency to multiply, and in some cases, to spread into surrounding tissues. Among various types of cancer, colorectal cancer and hepatocellular carcinoma are reported to be the 
most common forms [1]. Until recently, cancer patients have been treated with combinations of several therapies: chemotherapy, cytotoxic drugs, radiation, and surgical resection. However, these combined treatments, in particular, chemotherapeutic drugs produce significant side effects from which patients often suffer more than the from the cancer itself.

To alleviate these side effects, novel or alternative measures have been sought for drugs as treatments for cancer patients. One possible approach is the use of natural product therapy, a widely accepted alternative for cancer treatment. Because this therapy is based on plants or plant extracts, it usaully has less side effects, and lower costs for treatment. Recent studies indicated that some medicinal plants may have anticancer effects. Hajiaghaalipour et al [2] found that Camellia sinensis extract exhibited anti-proliferative effects on HT-29 cells. Devika and Mohandas [3] reported that extracts of Foeniculum vulgare induced apoptosis in cervical cancer cells and had anti-proliferative effects through DNA fragmentation. Manapradit et al [4] showed that butanolic leaf extracts from Barleria strigosa exhibited the highest cytotoxicity against the P-388 cell line with $\mathrm{CC}_{50}$ of $127.42 \mu \mathrm{g} \mathrm{mL}$.

Many plants growing in Thailand, including Camellia sinensis, Careya sphaerica, Cratoxylum formosum, Eleutherococcus trifoliatus, Ficus auriculata, Persicaria odorata, Schima wallichii, and Vaccinium sprengelii have been reported to have high polyphenol content and antioxidant activities [5].

Therefore, they were selected to investigate their cytotoxic and apoptotic abilities in colon and liver cancer cell lines.

\section{EXPERIMENTAL}

\section{Plant materials and reagents}

All plant materials were harvested from May to August in 2014 (Table 1). C. sphaerica and $C$. formosum were collected from Yasothon Province in the area of Khumkeunkaew District, while the other six plants were collected from Chiang Mai Province in the Fang District. The species of plants were identified by the Royal Project Foundation of Thailand. The voucher specimens of the plants were kept in the herbarium of Faculty of Agro-Industry at King Mongkut's Institute of Technology Ladkrabang (KMILT).The reagents, Rosewell Park Memorial Institute (RPMI) 1640 medium, fetal bovine serum (FBS), trypsin, and MTT reagent, 3-(4,5dimethylthiazol-2-yl) -2,5-diphenyltetrazolium bromide were purchased from Gibco, (El Paso,TX, USA). The blood DNA extraction kit and DNA markers were purchased from Vivantis, (Oceanside, CA, USA). Mitomycin C was purchased from Kyowa Hakko Kirin, (Tokyo, Japan).

\section{Preparation of plant extracts}

Samples were dried at $50{ }^{\circ} \mathrm{C}$ in a tray dryer until the moisture content was below $10 \%$. After cutting the dried sample into approximately $1 \mathrm{~cm}$ lengths, it was ground to a powder. The sample powder $(25 \mathrm{~g})$ was blended with $125 \mathrm{~mL}$ of $80 \%$ aqueous ethanol and extracted twice. The samples were first shaken at room temperature for $8 \mathrm{~h}$ and then filtered; the residues were extracted again using a ratio of 1:3 (dried sample : solvent) for an additional $8 \mathrm{~h}$. The extracts were combined and filtered using a $0.45 \mu \mathrm{m}$ filter and then concentrated in a rotary evaporator.

Table 1: Botanical name part used, and collection number of the eight edible Thai local plants

\begin{tabular}{|c|c|c|c|}
\hline Botanical name & Thai local name & Part used & Voucher no. \\
\hline $\begin{array}{l}\text { Camellia sinensis (L.) Kuntze var. assamica } \\
\text { (J.Masters) Kitam. }\end{array}$ & $\begin{array}{l}\text { Miang pa, Miang, } \\
\text { Miang Doi }\end{array}$ & Leaf & JUN2010 \\
\hline Careya sphaerica Roxb. & Kradon, Kradonbok & Leaf & MAY2011 \\
\hline Cratoxylum formosum (JACK) Dyer spp. & Tio khao ,Tio & Leaf & MAY2010 \\
\hline Eleutherococcus trifoliatus (L.) S.Y. Hu & Phak paem, Paem & Stem and leaf & MAY2013 \\
\hline Ficus auriculata Lour. & Duea wa & Leaf & JUN2013 \\
\hline Persicaria odorata (Lour.) Soja'k & Phak phai, Phak paew & Stem and leaf & AUS2010 \\
\hline Schima wallichii (DC.) Korth & Talo, Mung Tan & Leaf & AUS2010 \\
\hline Vaccinium sprengelii (G.Don) Sleumer & $\begin{array}{l}\text { Som Pi, Maohin, } \\
\text { Maohuawaen, } \\
\text { Sompae, Somsad }\end{array}$ & Leaf & JUN2010 \\
\hline
\end{tabular}


Dry crude extracts of $0.2 \mathrm{~g}$ were dissolved in 1 $\mathrm{mL}$ of $100 \%$ dimethyl sulfoxide (DMSO) and 9 $\mathrm{mL}$ of phosphate-buffered saline (PBS) was added to give a final concentration of $20 \mathrm{mg} / \mathrm{mL}$. The samples were kept at $-20{ }^{\circ} \mathrm{C}$ until use.

\section{Cell culture}

Colon cancer (human colon adenocarcinoma, HT-29) and liver cancer (human hepatocellular carcinoma, HepG2) were obtained from the National Cancer Institute in Thailand. Cells were grown in medium (RPMI 1640 containing $8 \%$ FBS) and gentamycin at $50 \mu \mathrm{g} / \mathrm{mL}$ ). The cells were cultured at $37{ }^{\circ} \mathrm{C}$ in humidified air with $5 \%$ $\mathrm{CO}_{2}$.

\section{MTT proliferation assay}

The MTT assay has been widely used as an indirect measure to determine the viability of cells. Itis a rapid and highly accurate colorimetric test that measures the decrease in the conversion of the MTT reagent (yellow colour) by mitochondrial succinate dehydrogenase. The MTT passes into the cell mitochondria membrane, and viable cells transform the yellowcoloured MTT to a purple-coloured formazan crystal. The MTT assay followed the method of Mosmann [6] with some modifications. HT-29 and HepG2 cell lines were grown overnight in 96well tissue culture plates with $1 \times 10^{5}$ cells per well. Then, the extract at a final concentration of $2,000 \mu \mathrm{g} / \mathrm{mL}$ was added for cytotoxic screening. The cells treated with mitomycin $C$ (cytotoxic drug) at $50 \mu \mathrm{g} / \mathrm{mL}$ were used as a positive control while negative control cells were treated with 0.2 $\%$ DMSO. Untreated cell cultures were used as a control and blank wells contained $100 \mu \mathrm{L}$ of medium without cells. The cells were cultured at $37{ }^{\circ} \mathrm{C}$ for $21 \mathrm{~h}$ under $5 \% \mathrm{CO}_{2}$ atmosphere. Then, $50 \mu \mathrm{L}$ of MTT $(2 \mathrm{mg} / \mathrm{mL})$ was added to each well for further incubation for 3-4 h. MTT crystals were solubilized with $100 \mu \mathrm{L}$ of a mixture of DMSO and absolute ethanol (ratio 1:1). The absorbance of each well was measured at 570 $\mathrm{nm}$ using a microplate reader. The percentage of cytotoxicity was determined using Eq 1.

Cell cytotoxicity $(\%)=\left(100-\frac{A s-A b}{A c-A b}\right) \times 100 \cdots .(1)$

where $A s, A b$ and Ac were the absorbances of the treated sample, blank, and control samples, respectively.

Plant extracts were selected and tested for the $50 \%$ cytotoxic concentration $\left(\mathrm{CC}_{50}\right)$. The final concentrations were $250,500,1,000,2,000$, and $4,000 \mu \mathrm{g} / \mathrm{mL}$. The $\mathrm{CC}_{50}$ values for growth inhibition were computed using GraphPad Prism 5 (La Jolla, CA, USA). All experiments were performed in triplicate.

\section{Morphological analysis}

HT-29 and HepG2 cells were treated with extracts at concentrations of 500 and 4,000 $\mu \mathrm{g} / \mathrm{mL}$ for $24 \mathrm{~h}$. Upon completion of incubation, morphological changes of cells were monitored under an inverted light microscope at 200x magnification.

\section{Apoptotic DNA ladder assay}

DNA fragmentation analysis was carried out using agarose gel electrophoresis as described by Herrman et al [7] with some modifications. The HT-29 and HepG2 cells were treated with each extract and then incubated for $48 \mathrm{~h}$. The treated cells were harvested by trypsinization, washed twice with PBS, and then used for DNA isolation. DNA extraction was performed using a blood DNA extraction kit as indicated in the manufacturer's guidelines. Electrophoresis was conducted at $100 \mathrm{~V}$ for $30 \mathrm{~min}$. The agarose gel was stained with ethidium bromide for $10 \mathrm{~min}$ and then rinsed in distilled water for another 10 min. The DNA bands were photographed under UV illumination. A $1 \mathrm{~kb}$ DNA marker was used to estimate the size of the DNA fragments.

\section{Statistical analysis}

Each experiment was run in triplicate. The results were reported as the mean \pm SD. Analysis of variance was performed by ANOVA tests and significant differences between means of cytotoxicity were $p<0.05$ using IBM SPSS software, version 24 (IBM Singapore Pte. Ltd., Changi, Singapore).

\section{RESULTS}

\section{Cell proliferation}

All the plant extracts exhibited different antiproliferative activity against HT-29 and HepG2 cells (Table 2). The plant extracts showed higher cytotoxicity for HT-29 cells than the positive control or the cytotoxic drug, mitomycin $\mathrm{C}$, at 50 $\mu \mathrm{g} / \mathrm{mL}$. $P$. odorata and $S$. wallichii extracts showed strong anticancer activity, particularly against HT-29 cells with cytotoxicity levels of more than $50 \%$ cell death. In the case of the HepG2 cells, no plant extracts showed stronger anticancer activity than the positive control. However, extracts from three species inhibited HepG2 cell growth relatively effectively: $V$. sprengelii, $P$. odorata and S. wallichii. 
Table 2: Cytotoxic activity on HT-29 and HepG2 cell lines of plant extracts at 2,000 $\mu \mathrm{g} / \mathrm{mL}$ and of mitomycin C at $50 \mu \mathrm{g} / \mathrm{mL}$

\begin{tabular}{lcc}
\hline Extract & \multicolumn{2}{c}{ Cytotoxic activity (\%) } \\
\cline { 2 - 3 } & HT-29 & HepG2 \\
\hline Camellia sinensis & $45.15^{\mathrm{b}} \pm 13.22$ & $44.38^{\mathrm{a}-\mathrm{d}} \pm 15.45$ \\
Careya sphaerica & $37.52^{\mathrm{b}} \pm 3.83$ & $31.24^{\mathrm{a}-\mathrm{c}} \pm 15.35$ \\
Cratoxylum formosum & $35.25^{\mathrm{b}} \pm 5.95$ & $17.13^{\mathrm{a}} \pm 0.58$ \\
Eleutherococcus trifoliatus & $35.51^{\mathrm{b}} \pm 2.08$ & $45.06^{\mathrm{a}-\mathrm{d}} \pm 15.73$ \\
Ficus auriculata & $31.02^{\mathrm{b}} \pm 2.11$ & $30.56^{\mathrm{ab}} \pm 7.04$ \\
Persicaria odorata & $66.86^{\mathrm{c}} \pm 12.95$ & $68.94^{\mathrm{d}} \pm 17.70$ \\
Schima wallichii & $65.42^{\mathrm{c}} \pm 2.64$ & $64.95^{\mathrm{cd}} \pm 12.04$ \\
Vaccinium sprengelii & $42.29^{\mathrm{b}} \pm 12.53$ & $62.20^{\mathrm{cd}} \pm 7.76$ \\
Mitomycin C & $17.32^{\mathrm{a}} \pm 3.75$ & $81.35^{\mathrm{a}} \pm 10.18$ \\
\hline icantly different at $p<0.05$ & &
\end{tabular}

${ }^{a-e}$ Significantly different at $p<0.05$

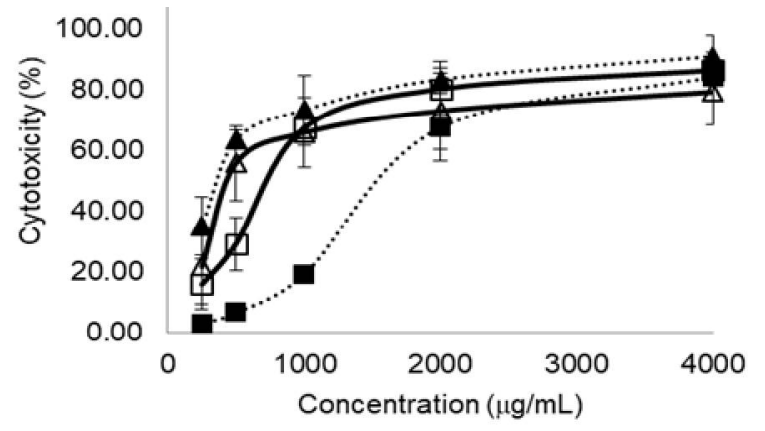

Figure 1: The $50 \%$ cytotoxic concentration $\left(\mathrm{CC}_{50}\right)$; $P$. odorata, $\Delta$ S. wallichii in HepG2 and $\square$ P. odorata, $\Delta$ S. wallichii in HT-29 cell lines

The MTT assay data indicated that the extracts from $S$. wallichii and $P$. odorata possessed strong anti-proliferative activity in both cell lines. Therefore, they were selected for further studies to determine the $\mathrm{CC}_{50}$. The level of cytotoxicity generally increased gradually with increasing concentrations of the extracts (Figure 1). The $S$. wallichii extract had greater cytotoxic activity than the $P$. odorata extract in both cell lines. The $\mathrm{CC}_{50}$ of the S. wallichii extract on HT-29 cells was 453 $\mu \mathrm{g} / \mathrm{mL}$, and $367 \mu \mathrm{g} / \mathrm{mL}$ for HepG2 cells. The $\mathrm{CC}_{50}$ of the $P$. odorata extract on HT-29 cells was $775 \mu \mathrm{g} / \mathrm{mL}$ and $1,665 \mu \mathrm{g} / \mathrm{mL}$ for HepG2 cells. The $\mathrm{CC}_{50}$ of the $S$. wallichii extract was 1.7 and 4.5 times greater than that of $P$. odorata extract against HT-29 and HepG2 cells, respectively. The results indicate that the $S$. wallichii extract had significantly greater cytotoxicity than the $P$. odorata extract against both cell lines.

\section{Morphological changes}

The effects of $S$. wallichii and $P$. odorata extracts on cell morphology of HT-29 and HepG2 cells were observed using inverted light microscopy. No morphological changes were observed in control cells; however, both extract treatments resulted in morphological changes in a concentration-dependent manner (Figure 2). The two extracts $(500 \mu \mathrm{g} / \mathrm{mL}$ each) induced changes in morphologies of HT-29 and HepG2 cells indicating an early stage of apoptosis, including cell shrinkage. The cytoplasm was denser and the shape more tightly packed in the treated cells. As the concentration of extracts increased to $4,000 \mu \mathrm{g} / \mathrm{mL}$, the loss of cell adhesion, reduced cell density, and membrane blebbing occurred.

\section{Apoptotic DNA ladder}

DNA fragmentation is an important characteristic of apoptosis. Prior to the fragmentation of the nucleus, condensation and degradation of chromatin/DNA were observed. Cheung et al [8] reported that the first marker in the apoptosis process was DNA laddering, which is a sign of cell death. Following chromatin condensation, caspase activated DNase (CAD) degrades DNA and caspase-3-treated cell lysates are observed [9]. Figure 3 ( $A$ and $B$ ) shows that the extracts induced DNA fragmentation in HT-29 and HepG2 cells. Cells treated with $S$. wallichii and $P$. odorata extracts showed a smear pattern when compared with the DNA ladder; in contrast, the smear pattern of damaged DNA was not observed in control cell samples. Apoptosis was therefore induced by the extracts in HT-29 and HepG2 cells.

Both extracts showed a concentration-dependent pattern of DNA fragmentation. In the case of HT29 cells, $S$. wallichii extract was more effective than $P$. odorata extract (Figure 3A). Conversely, with HepG2 cells the $P$. odorata extract was more effective than the $S$. wallichii extract (Figure 3B). As a positive control, mitomycin C (100 $\mu \mathrm{g} / \mathrm{mL}$ ) caused more DNA fragmentation in HepG2 cells compared to HT-29 cells than the two extracts. 

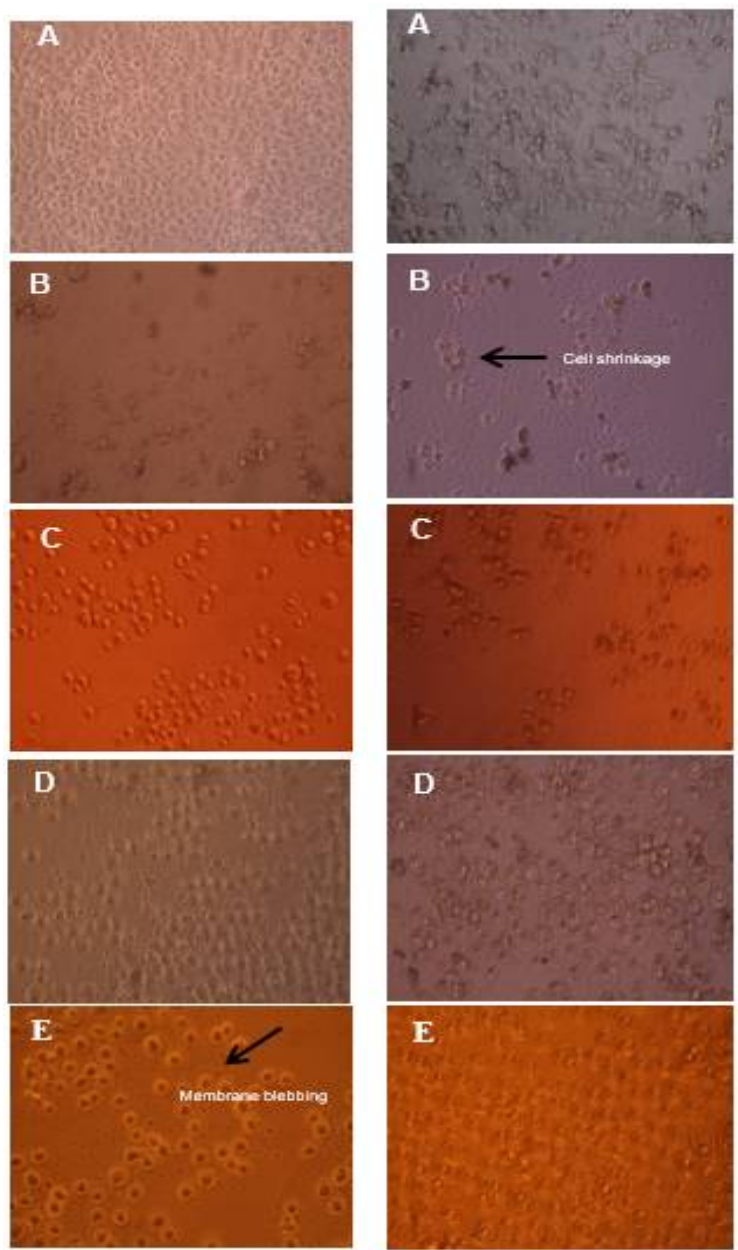

Figure 2: Photomicrographs (200x) of $P$. odorata (PP) and S. wallichii (TL) extract-treated HT-29 cells (left) and HepG2 cells (right); A: cells without treatment (control), B-C: PP at 500 and $4,000 \mu \mathrm{g} / \mathrm{mL}$, D-E: TL at 500 and $4,000 \mu \mathrm{g} / \mathrm{mL}$. Arrows indicate cell shrinkage and membrane blebbing

\section{DISCUSSION}

The potent biological activities of plant extracts are associated with their phytochemical constituents. $P$. odorata, $S$. wallichii, and $V$. sprengelii have been reported to have high polyphenol content [5]. Polyphenols induce proapoptotic properties. Ramos [9] described the pro-apoptotic effects of dietary polyphenols on various human cancer cell lines including colon, prostate, lung, breast cancer and leukaemia.

The major phytochemicals of $S$. wallichii include saponins and tannins [10]. Saponins, triterpenoid glycosides, show different biological activities and have the potential for pharmaceutical applications [11]. They reportedly prevent the proliferation of cancer cells [12]. Hu et al [13] identified a compound, Nigella A, which was extracted from Nigella glandulifera (Nepenthaceae) and reported to be the major triterpene saponins.

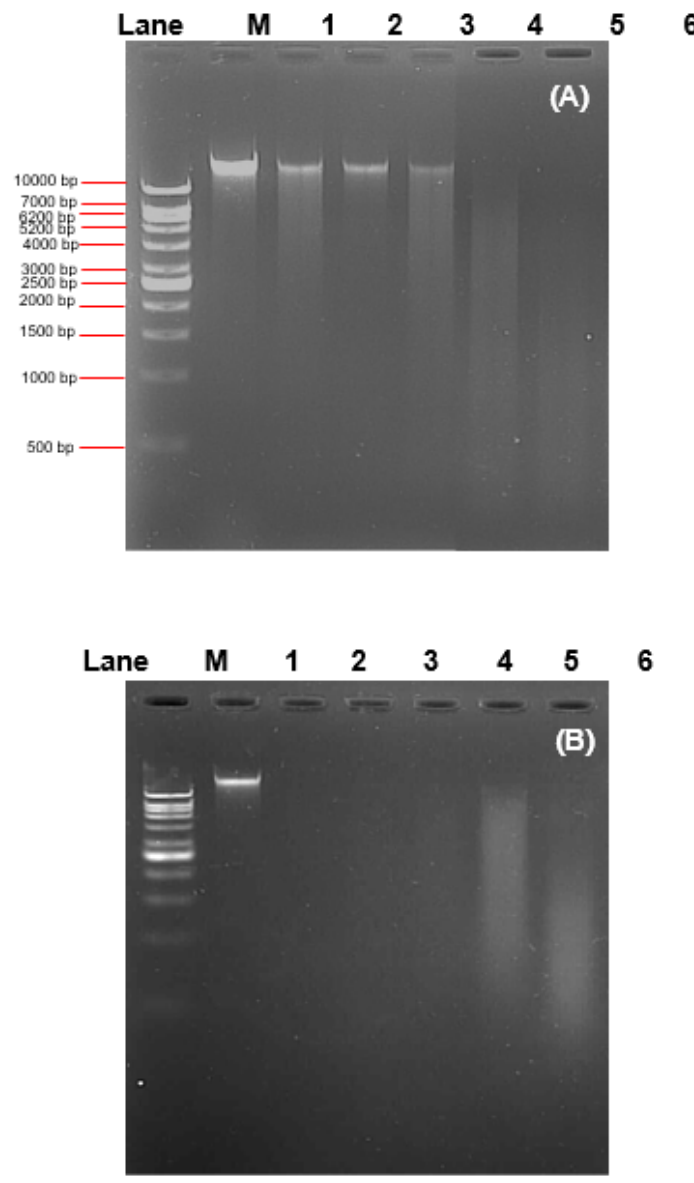

Figure 3: Agarose gel electrophoresis of DNA fragmentation patterns in HT-29 cells (A) and HepG2 cells $(\mathrm{B})$ treated with $P$. odorata $(\mathrm{PP})$ and $S$. wallichii (TL) extracts for 48 h. M. marker, $1 \mathrm{~kb}$; 1, control; 2 , positive control $(100 \mu \mathrm{g} / \mathrm{mL})$; $3-6$, cells treated with PP $(500 \mu \mathrm{g} / \mathrm{mL})$, PP $(1,000 \mu \mathrm{g} / \mathrm{mL})$, TL $(500 \mu \mathrm{g} / \mathrm{mL})$, or TL $(1,000 \mu \mathrm{g} / \mathrm{mL})$, respectively

This compound inhibited the growth of human lung carcinoma A-549 cells. Saponin separated from the leaves of Panax notoginseng (Araliaceae) demonstrated cytotoxic effects against four cancer cells; KP4 cells (human pancreatic cancer), $\mathrm{NCl}-\mathrm{H} 727$ cells (human lung cancer), HepG2 cells (human hepatocellular cancer) and SGC-7901 cells (human gastric adenocarcinoma) [14].

Tannins also exhibit biological activities such as anticancer activity. Hydrolysable tannin isolated from Cuphea hyssopifolia (Lythraceae) showed antitumor activity on HL-60 cells [15]. Gallotannin inhibited cell growth and induced apoptosis in T84 cells (human colon cancer) [16].

Flavonoids were reported to be the main phytochemical responsible for anticancer activity in $P$. odorata [17]. The biological activities of flavonoids include anti-inflammatory, antispasmodic, and anti-allergic activities as well as 
protective activities for hepatic and vascular disorders [18]. Flavonoids also show anticancer activity in various cancer cells. For example, (+)catechin and (-)-epicatechin play a role in protecting liver cancer cells from DNA damage against $\mathrm{N}$-nitrosodimethylamine, nitrosopyrrolidine and benzo (a) pyrene [19].

The $\mathrm{CC}_{50}$ showed that the $S$. wallichii extract was more effective against HepG 2 cells than HT-29 cells (Figure 1), which indicated that the phytochemical in $S$. wallichii extracts was more sensitive and specific for HepG2 than HT-29 cells. In addition, the anticancer activity of phytochemicals mainly depends on their multitarget mechanisms of action, including antimutagenic, antioxidant and, anti-proliferative activities [20].

The cytotoxic activity assay of crude extracts showed potential against cancer cell lines, which were in accordance with Momtazi-Borojeni et al [21], that crude methanol extract of Avicennia marina potentially inhibited the viability of MDAMB 231 cells (human breast cancer cell) with a $\mathrm{CC}_{50}$ value of $250 \mu \mathrm{g} / \mathrm{mL}$. For the rhabdomyosarcoma (RD) tumour cell line and murine fibroblast (L20B) cell line, the crude methanol extract of Nicotiana tabacum showed $\mathrm{CC}_{50}$ values of $2,100 \mu \mathrm{g} / \mathrm{mL}$ for $\mathrm{RD}$ and 2,150 $\mu \mathrm{g} / \mathrm{mL}$ for L20B cells after $72 \mathrm{~h}$ [22].

The morphological changes increased as the extract concentration increased, and were characteristics of apoptotic cell death. Apoptosis can occur via two routes, either extrinsic (activation of death receptors) or intrinsic (mitochondrial-mediated) pathways. In this study, increasing the concentration of the extracts was expected to induce the intrinsic pathway. The intrinsic signaling pathway activation occurs first, following by mitochondrial outer membrane permeabilization resulting in the release of prodeath factors into the cytosol [23].

$P$. odorata extract more effectively caused DNA fragmentation than the $S$. wallichii extract at both concentrations. The phytochemicals in the $P$. odorata extract may activate the caspase family of proteases better than the $S$. wallichii extract, and eventually lead to the degradation of chromosomal DNA in HepG2 cells.

$P$. odorata extract therefore has a higher potential for DNA fragmentation than $S$. wallichii extract in HepG2 cells. Increasing the concentration of $P$. odorata and $S$. wallichii extracts resulted in the typical DNA laddering in agarose gels, due to activation of caspase enzyme activity and oxidative stress in cells as observed in both cell lines.

The results using $S$. wallichii extract were similar to those of Halimah et al [24] who showed that the major compound (kaempferol-3-Orhamnoside) in the ethylacetate fraction of. $S$. wallichii inhibited MCF-7 cell growth via activation of caspase- 9 and caspase- 3 , inducing apoptosis.

The effect of $P$. odorata extract on HepG2 cells regarding the fragmentation of DNA was opposite to the $\mathrm{CC}_{50}$ observed from MTT results (Figure 1). S. wallichii extract was more effective than the $P$. odorata extract. The MTT assay is an indirect measurement of mitochondria effects. The plant extracts inhibited succinate dehydrogenase in the mitochondria, which could hinder reactions with MTT reagent to form formazan crystals. However, DNA fragmentation is associated with caspase-3-mediated cleavage releasing caspase activated DNase (CAD) and resulting in degradation of DNA into oligonucleosomal fragments [25].

\section{CONCLUSION}

The results of this study demonstrate that all the plant extracts examined in this study exert cytotoxic activity against colon cancer cells. Of the eight plant species studied, $P$. odorata and $S$. wallichii extracts possess the highest antiproliferative activity against colon and liver cell lines, and they also induce apoptosis by DNA fragmentation, thus demonstrating their potentials as anticancer chemotherapeutic agents. Further studies, however, are needed to isolate their active compounds.

\section{DECLARATIONS}

\section{Acknowledgement}

The authors would also like to thank the Royal Project Foundation for providing plant samples for this study.

\section{Conflict of interest}

No conflict of interest is associated with this work.

\section{Contribution of authors}

The authors declare that this work was done by the authors named in this article and all liabilities pertaining to claims relating to the content of this article will be borne by them. 


\section{REFERENCES}

1. American Cancer Society. Cancer Facts \& Figures 2015. American Cancer Society, Inc., Atlanta.

2. Hajiaghaalipour $F$, Kanthimathi MS, Sanusi J, Rajarajeswaran J. White tea (Camellia sinensis) inhibits proliferation of the colon cancer cell line, HT-29, activate caspases and protects DNA of normal cell against oxidative damage. Food Chem 2015; 169: 401-410.

3. Devika V, Mohandass S. Apoptotic induction of crude extract of Foeniculum vulgare extracts on cervical cancer cell lines. Int J Curr Microbiol Appl Sci 2014; 3(3): 657-661.

4. Manapradit N, Poeaim S, Charoenying P. Cytotoxicity and antimicrobial activities of leaf extracts from Barleria strigosa. Int J Agric Technol 2015; 11(2): 551-561.

5. Putthawan $P$, Areekul V. Screening for antioxidant activity in edible Thai local plants. Proceeding of Natural Products Research and Development Center, Chiang Mai, Thailand; 2012; pp 846-850.

6. Mosmann T. Rapid colorimetric assay for cellular growth and survival: application to proliferation and cytotoxicity assays. J Immunol 1983; 65: 55-63.

7. Herrmann H, Lorenz HM, Voll R, Grunke M, Woith W, Kalden JR. A rapid and simple method for the isolation of apoptotic DNA fragments. Nucleic Acids Res 1994; 22(24): 5506-5507.

8. Cheung WL, Ajiro K, Samejima K, Kloc M, Cheung $P$, Mizzen $C A$, Beeser A, Etkin $L D$, Chernoff J, Earnshaw WC, Allis $C D$. Apoptotic phosphorylation of histone H2B is mediated by mammalian strerile twenty kinase. Cell 2003; 113(4): 507-517.

9. Ramos S. Effects of dietary flavonoids on apoptotic pathways related to cancer chemoprevention. J Nutr Biochem 2007; 18(7): 427-442.

10. Burkill IH. A dictionary of the Economic Products of the Malay Peninsula. Ministry of Agriculture and Cooperatives Kuala Lumper, Malaysia. 1996.

11. Faizal A, Geelen D. Saponins and their role in biological processes in plants. Phytochem Rev 2013; 12(4): 877893.

12. Yildirim I, Kutlu T. Anticancer Agents: Saponin and Tannin. Int J Biol Chem 2015; 9(6): 332-340.

13. Hu X, Liu X, Gong M, Luan M, Zheng Y, Wu G., Shentu $J$, Zhang L. Development and validation of liquid chromatography-tandem mass spectrometry method for quantification of a potential anticancer triterpene saponin from seeds of Nigella glandulifera in rat plasma: Application to a pharmacokinetic study. J Chromatogr $B$ 2014: 967: 156-161.
14. Qian M, Yi L, Song-Lin L, Jie Y, Ping-Hu Z, Qiang W. Chemical profiles and anticancer effects of saponin fractions of different polarity from the leaves of Panax notoginseng, Chinese. J Nat Med 2014; 12(1): 30-37.

15. Wang CC, Chen LG, Yang LL. Cuphiin D1, the macrocyclic hydrolyzable tannin induced apoptosis in HL-60 cell line. Cancer Letters 2000; 149(1-2): 77-83.

16. Gali-Muhtasib HU, Youne IH, Karchesy JJ, El-Sabban ME. Plant tannins inhibit the induction of aberrant crypt foci and colonic tumors by 1,2-dimethylhydrazine in mice. Nutr Cancer 2001; 39: 108-116

17. Wojdylo A, Oszmianski J, Czemerys R. Antioxidant activity and phenolic compounds in 32 selected herbs. Food Chem 2007; 15(3): 940-949.

18. Okuda T, Yoshida T, Hatano T. Polyphenol from Asian plants, structural diversity and antitumor and antiviral activities. In Phenolic Compounds in Food and Their Effects on Health II, Antioxidants and Cancer Prevention; Haung, M.-T., Ho, C-T., Lee, C.Y., Eds.; American Chemical Society, Washington DC, USA; 1992; pp 160-183.

19. Delgado ME, Haza Al, Arranz N, Garcia A, Morales P. Dietary polyphenols protect against $\mathrm{N}$-nitrosamines and benzo (a) pyrene-induced DNA damage (strand breaks and oxidized purines/pyrimidines) in HepG2 human hepatoma cells. Eur J Nutr 2008; 47: 479-490.

20. Catalano E. Role of phytochemicals in the chemoprevention of tumors, 2016. Available from https://arxiv.org/ftp/arxiv/papers/1605/1605.04519.pdf

21. Momtazi-Borojeni AA, Behbahani $M$, Sadeghi-aliabadi $H$. Antiproliferative Activity and Apoptosis Induction of Crude Extract and Fractions of Avicennia Marina. Ira J Basic Med Sci 2013; 16(11): 1203-1208.

22. Asaad ABAA, Nadya YA, Twana AM. Cytotoxic and cytogenetic effects of aqueous and methanol crude extracts of Nicotiana tabacum on Rhabdomyosarcoma $(R D)$ and L20B cell lines in vitro. Euro J Exp Bio 2014; 4(2): 164-171.

23. Saelens $X$, Festjens $N$, Vande WL, Van GM, Van LG, Vandenabeele $P$. Toxic proteins released from mitochondria in cell death. Oncogene 2004; 23(16): 2861-2874.

24. Halimah E, Diantini D, Destiani, D, Pradipta I, Sastramihardja H, Lestari K, Subarnas A, Abdulah R, Koyama $\mathrm{H}$. Induction of caspase cascade pathway by kaempferol-3-O-rhamnoside in LNCaP prostate cancer cell lines. Biomed Rep 2015; 3(1): 115-117.

25. Enari M, Sakahira H, Yokoyama H, Okawa K, Iwamatsu A, Nagata S. A caspase-activated Dnase that degrades DNA during apoptosis, and its inhibitor ICAD. Nature 1998; 391: 43-50. 